\title{
Obituaries
}

\section{PETER McPHILLIPS}

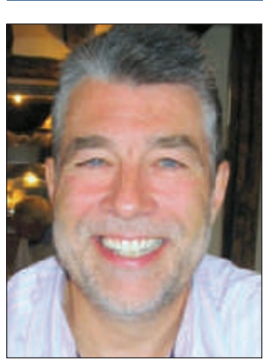

The whole dental community in Northern Ireland was shocked and saddened to learn that Peter McPhillips had died suddenly and unexpectedly on 5 March, at his home in Carlingford, six days after celebrating his 56th birthday.

Born in London, Peter's early years were spent in Belfast before going to St MacNissi's boarding school. Some people may be surprised that he was almost expelled, his crime, brewing beer in the dormitory. Peter would never get into trouble for an ordinary misdemeanour, however, brewing beer, that would be Peter.

Peter qualified from Queen's University Belfast in 1978 having supplemented his grant by working as a DJ, beginning his lifelong love of gadgets and music.

Peter opened his own practice in Coalisland in 1980. In the 26 years running his own practice the strangest payment he ever received was turnips. We don't know what the exchange rate of fillings to turnips was.

Peter gained membership of The Faculty of General Dental Practitioners in 1993, was a member of The Irish Society of Clinical and Academic Hypnosis and also completed an MBA with the Open University Business School.

Peter got involved early with dental politics and went on to chair Northern Ireland GDSC for nine years serving on national GDPC executive, as well as being elected to the BDA Representative Board. Every practitioner in Northern
Ireland owes Peter a debt of gratitude, whether they know it or not.

After selling his practice Peter concentrated on working as a dental adviser for the Southern Health Board and for Dental Protection. His great experience and business acumen made him perfect for these jobs and though often exasperated by his colleagues' acts, he never judged, he just sorted things out.

Peter loved life. He proudly completed his yacht skippers' exams and was active hill walking in the Mournes and skiing in Vallorcine. He had a knowledge and love of fine food and wine, was good company and a good friend.

The Northern Ireland Branch extend condolences to Peter's mother and father, partner Jennifer, children Zita, Rory, Conal and their mother Catherine.

$B M c G, R G$

\section{DAVID LOCKER}

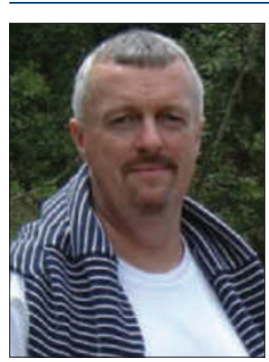

Professor David Locker, Associate Dean in the Faculty of Dentistry in the University of Toronto, died on 22 April 2010 after a short illness, leaving an academic legacy the like of which only very few can hope to achieve. Born in Derbyshire in 1949, David graduated from the University of Sheffield with BDS Honours in 1971 followed by diplomas in Health Services Administration, Sociology and then a PhD in Sociology.

Many prizes and honours followed, including the IADR Distinguished Scientist Award for Behavioural Sciences and Health Services research in 1998 and the AADR William J. Gies Award for
Obituaries should be submitted by email to Kate Maynard at k.maynard@nature.com.

All submitted obituaries should be 350 words maximum in length (apart from obituaries for past presidents of the BDA where the length should be $700-800$ words) Content of the obituary is down to the individual author, and the approval of the family should be given for the obituary prior to submission to the $B D J$.

the best paper published in the Journal of Dental Research in 1999.

David joined the Faculty of Dentistry in the University of Toronto in the Department of Community Dentistry as an Associate Professor in 1985 and full Professor in 1990. In 1991 he won funding from the Ontario provincial government to found the well-known and paradigm-shifting Community Dental Health Research Unit.

Sitting on four editorial boards and attracting phenomenal amounts of research funding for his inspired, and inspiring, work, he published five books, 19 book chapters and 250 papers in academic journals, being globally regarded as a thought-provoking and exciting speaker. David's charisma, charm and humour made him deeply loved by many and his wit could reduce an entire gathering to tears of laughter. His merry spirit and huge capacity for nonsense, fun and laughter created a rollercoaster ride of new experiences for his friends and work colleagues. Travel and socialising were the stuff of life for David and many found their lives transformed by his passionate commitment to open-minded thought and philosophical fairness.

Despite this, David was a very humble, and quite shy individual but also very loving and extraordinarily generous; always willing to give his time, experience, intellect and gifts. He was also, it may surprise many, an amazingly talented dancer, even to the point of performing with a contemporary dance group in Canada. David leaves behind him his brother and his family, his great friends and a host of colleagues who adored him.

EK 